Article

\title{
Temporal Continuities of Grasslands and Forests as Patches of Natural Land in Urban Landscapes: A Case Study of the Tsukuba Science City
}

\author{
Shoma Jingu ${ }^{(D)}$ \\ Faculty of Human Sciences, Waseda University, Tokorozawa City, Saitama 359-1192, Japan; jingu@aoni.waseda.jp \\ Received: 11 October 2020; Accepted: 30 October 2020; Published: 31 October 2020 \\ check for
}

\begin{abstract}
Development has fragmented urban nature, and target sites for conservation strategies need to be those that have long maintained their original land cover in a clustered area. Additionally, continuously grasping changes from rural to urban as well as changes over decades after urbanization is essential. Therefore, this study identified and investigated natural patches in urban landscapes, clarified actual management practices in the identified patches, and traced changes in land ownership and land cover during the past 130 years in the Tsukuba Science City, Japan. We first identified areas containing clusters of urban grasslands and forest patches that have existed since the 2010s. We then identified urban green space patches that since the 1880s have remained undeveloped after being agricultural landscapes, despite the rapid urbanization of the Tsukuba Science City since the 1970s. These patches of urban green space were mainly identified near rural communities, research institutions, planned development sites, and golf courses. The findings of this study highlighted the need for new policy implications through systematic arrangement of diverse conservation strategies to maintain urban green space patches. Further investigation is required to elucidate the ecosystem services provided by these remnant green patches.
\end{abstract}

Keywords: land cover change; human-modified landscape; spatial autocorrelation; urban ecosystem; conservation strategy

\section{Introduction}

Biodiversity, ecology, ecosystem services, and social and cultural values are all important factors of nature conservation, not only in protected areas such as national parks but also in human-made environments that have been affected by human influence for many years [1]. An example of a human-modified landscape is agricultural landscapes formed by rural communities. In terms of human interactions with nature, agriculture has been the primary use of land from time immemorial. This has however been blamed as a major factor in the loss of wild nature, biodiversity, local richness, and ecosystem services [2-4]. Modern agriculture, which priority is given to maximizing food production, has been leading to the loss of biodiversity and ecosystem services [5]. This has been counteracted, in recent years, by the creation of human-modified landscapes by traditional agricultural landscapes, which have helped maintain a rich biodiversity and provided many ecosystem services [6-8].

In addition to agricultural landscapes, the natural patches left in urban landscapes are also important as one form of human-modified landscapes. Urban nature includes a range of habitat types that cross a continuum from intact remnant patches of native vegetation to green infrastructure habitats such as managed parks, home gardens, and green roofs, with semi-natural ecological systems such as riparian corridors and urban wastelands [9]. Urban nature is characterized by landscape management and multi-level human-made impacts $[9,10]$. Thus, the human-modified landscapes 
prioritized for conservation would be maintained as parts of urban nature if human influences, such as green space management, reach the patches of native vegetation left after the development of agricultural landscapes.

Natural patches left in urban landscapes have garnered significant attention for the various ecosystem services they provide, such as improving biodiversity conservation and scenic beauty as well as providing recreation sites that are fundamental to humans' wellbeing [9-14]. Unfortunately, urban nature has been fragmented by development, and the target sites for conservation strategies need to be those that have maintained their original land cover in a clustered area over a long term $[15,16]$. Also, socio-economic and cultural impacts are complex in cities. Biodiversity is threatened by the general style of parks and green space management practices, such as lawn maintenance, and the introduction of non-native plant species, even in reserved natural environments like parks and green spaces [9]. Therefore, strategies or compromises are needed to balance socio-economic priorities with the values to be protected, such as biodiversity conservation $[9,17]$.

However, little attention has been paid to the different ways that these natural patches have managed to survive over multiple decades. Various studies have provided guidance for planning and policy implications that achieve conservation of urban natural patches by revealing changes in land cover over the last 20 to 30 years [18-21]. These studies have focused on two aspects of a city's change. The first aspect concerns before-and-after changes from rural to urban. The other is observation of minor changes after a city's establishment. Immediately after urbanization, remnants of agricultural landscape as a modified natural environment would be present in the city's green areas. In urban green spaces, however, the agricultural landscape changes gradually to dense, rich greenery due to decades of excessive management, or, conversely, abandonment of management $[18,19,22,23]$. Therefore, continuously grasping changes from rural to urban and changes over decades after urbanization is necessary.

This study's objective is to determine areas in urban nature that are less fragmented, barely affected by urban development, and have a long history of their management's current status. In the Tsukuba Science City, previous research has clarified changes in green spaces and management issues for about 30 years after development [22-24]. In this study, we identified and investigated natural patches in urban landscapes, clarified actual management practices in the identified patches, and traced changes in land ownership and land cover during the past 130 years.

\section{Materials and Methods}

\subsection{Study Site}

This study was conducted in the Tsukuba Science City, Tsukuba City, Ibaraki Prefecture, located approximately $50 \mathrm{~km}$ northeast of Tokyo, Japan (Figure 1). Tsukuba City is part of the Kanto Plain, which has been part of the Tokyo Metropolitan area since the 19th century, and has served as a supplier of natural resources such as firewood to large cities since the 17th century [25-27]. The city's northern part is mountainous, formed by magma deep underground and great movement of oceanic plates, while the southern part is a Pleistocene plateau plain. Tsukuba Science City was planned and developed by the national government to alleviate the Tokyo metropolitan area's concentrated population and so began life as an instance of the international garden-campus-suburb orthodoxy surrounding science spaces $[23,28]$. Public and private research institutes as well as the University of Tsukuba (formerly the Tokyo University of Education) were moved from Tokyo to Tsukuba. Subsequently, residential areas developed in and around the science city.

The Tsukuba Science City was established in the 1970s after the urbanization of rural communities located on the plain at an altitude of $20 \mathrm{~m}$. Parts of the natural environment, which were agricultural landscapes, were replaced with green spaces based on an urban plan from the 1970s whose principles are still at the core of municipal management plans in the 2010s [29,30]. Specifically for this project, while developing each of the large-scale public facilities, about $30 \%$ of the site was reserved as 
green space, taking advantage of the characteristics of the existing land cover. This period of urban development coincided, in the 1970s, with the decline in the value of maintaining human-modified landscapes in rural communities after decreasing the use of natural resources in the 1960s.

It is clear that the study site and its surroundings had a land cover pattern of habitation, crops and rice paddies, forests, and grasslands that represented the Japanese traditional agricultural landscape [31-35]. Several studies on the transformation of the natural environment in rural communities due to the development of the Tsukuba Science City have reported that the conversion from forest to agricultural land after WWII was limited to a few areas, and agricultural landscapes such as pine forests were maintained as a flatland forest for compost and fuel demand until the 1960s [35,36]. The studies also found that $55.9 \%$ of the land for the urban development in the 1970s came from rural community forests [35]. Therefore, it is highly likely that agricultural landscapes will remain in human-modified urban landscapes.

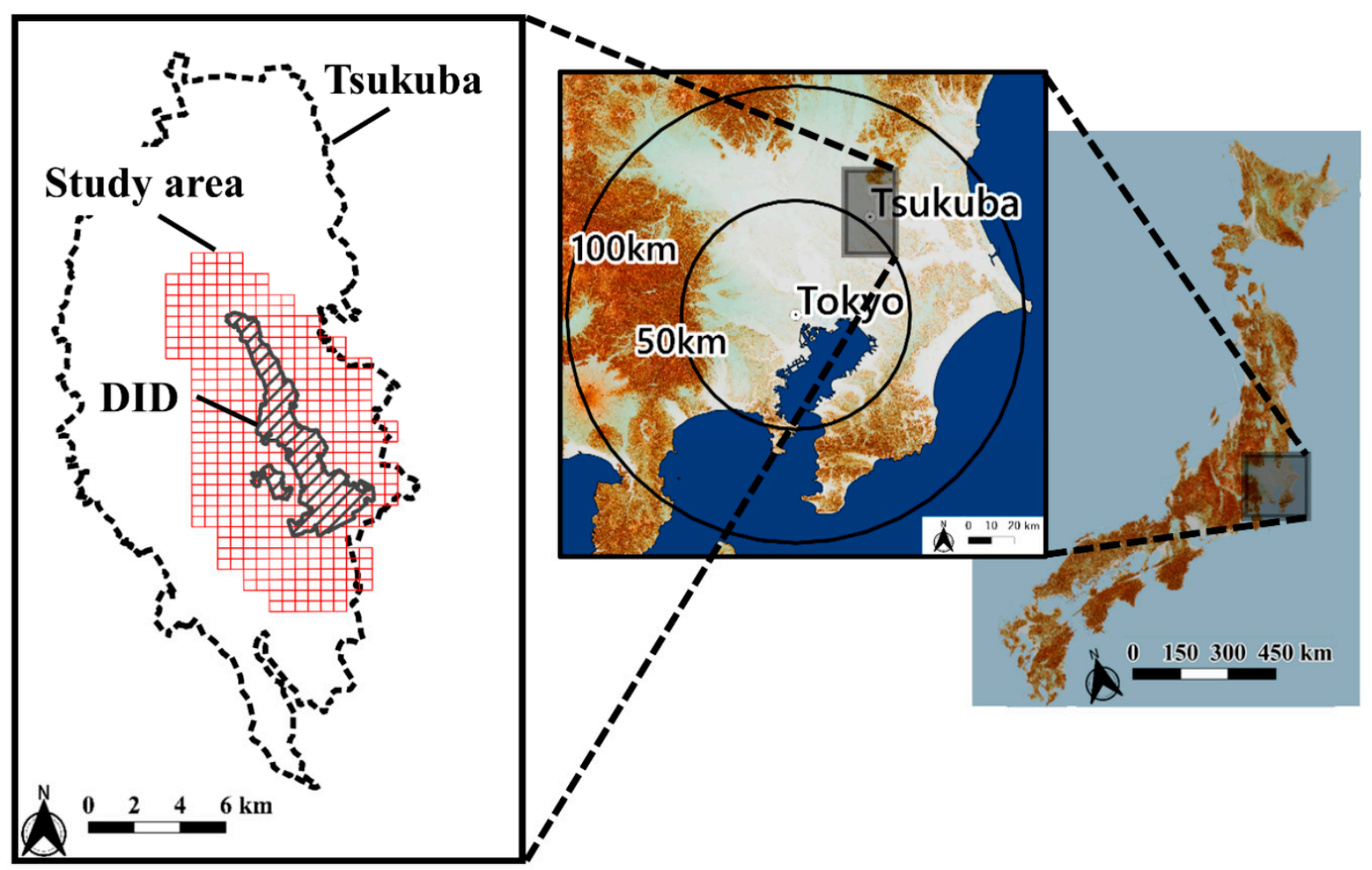

Figure 1. Study site in Japan, Kanto region and Tsukuba City. The study site is defined based on the Fourth Standard Grids (FSGs) of Japan [38] and the distance from the Densely Inhabited District (DID) surveyed in 2015 [37]. Japan and Kanto region maps are CS 3D-Map based on the Digital Map (Basic Geospatial Information) published by the Geospatial Information Authority of Japan. Dark brown means high elevation, high slope, and high curvature.

The agricultural landscape predated the development of the Tsukuba Science City in the 1960s, although there was the Aerological Observatory, which was established in the 1920s. The natural environment in urbanized areas was created after the development of the Tsukuba Science City in the 1970s. Two big projects contributed significantly to the rapid expansion of urbanized areas in the area: the International Exposition, Tsukuba 1985 and the development of new districts with the opening of railways in the 2000 s.

Figure 1 shows the coverage of the study site. The Tsukuba Science City is the central urban area in Tsukuba City, Ibaraki Prefecture, and the core is composed of a Densely Inhabited District (DID) which is a classification on the statistical survey in Japan [37]. Since there are no clear boundaries in the Tsukuba Science City, the study site is defined based on the Fourth Standard Grids (FSGs) of Japan, a national grid system with an approximately $500 \mathrm{~m}$ grid pattern $(22.5 \mathrm{~s}$ in longitude, $15 \mathrm{~s}$ 
in latitude) [38]. We selected FSGs located within $3 \mathrm{~km}$ of the DID surveyed in 2015. Note that the DID area has not changed significantly since 1990. The area that we analyzed is about 10,200 ha with 408 grids.

\subsection{Dataset for Comparison of Past and Present Land Ownership and Land Cover}

First, we highlighted the land cover in the 2010s and investigated the patches of natural environments left in the urbanized area. Second, we investigated 130-year temporal continuities of the patches (Figure 2). For the spatio-temporal analysis, we analyzed land dynamics from the nine time periods (1880s-2010s) using sets of aerial photographs and topographic maps created by the Geospatial Information Authority (GSI) of Japan [39], the national surveys of the natural environment vegetation map [40,41], and the Land Use and Land Cover Map provided by the Japan Aerospace Exploration Agency (JAXA) [42] (Table S1).

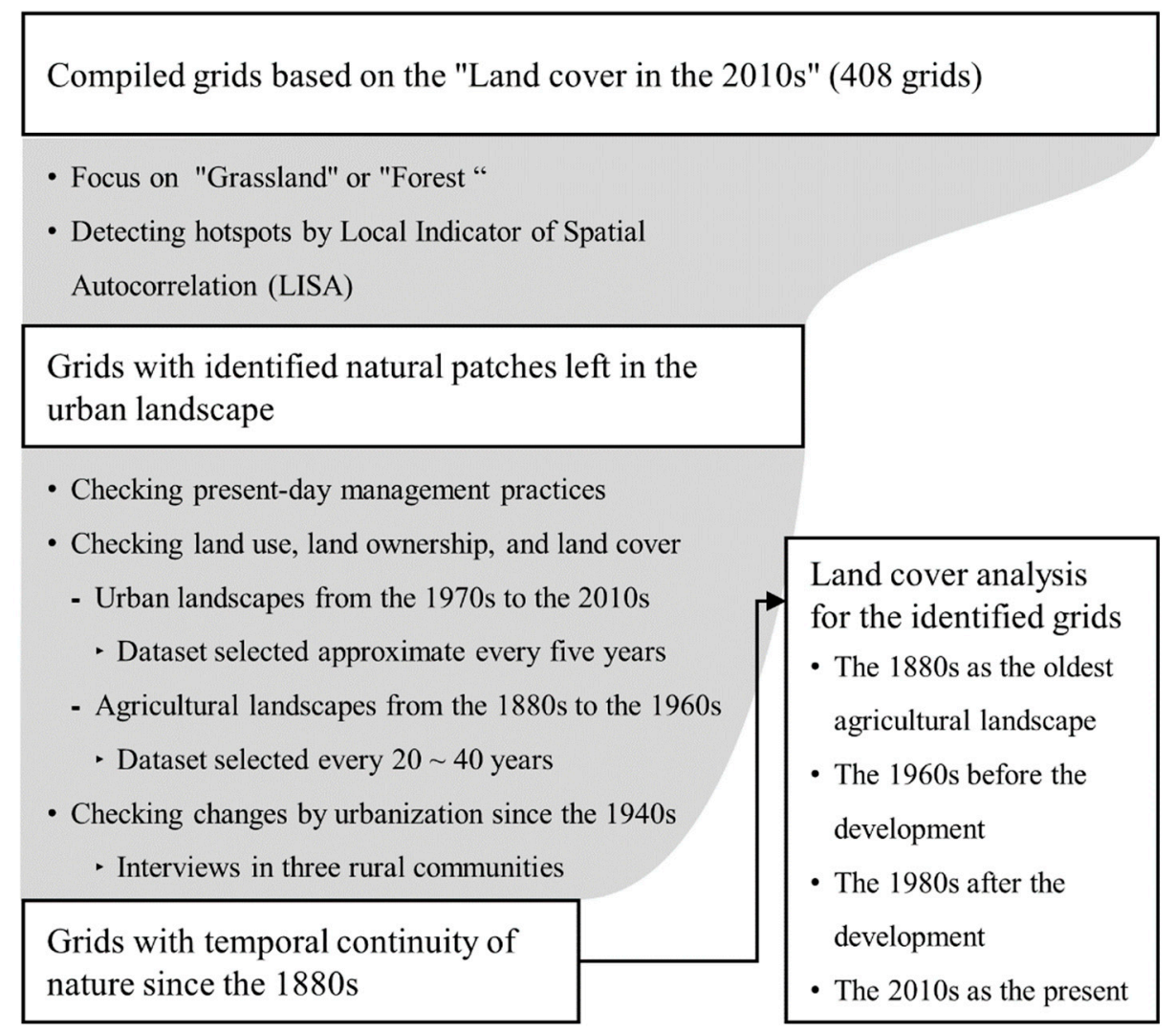

Figure 2. Flow chart of the study's processes and sources.

The oldest period is the 1880s based on the rapid survey maps (topographic maps), the first Japanese maps made using modern surveying methods. The rapid survey maps enabled us to see and verify Japanese agricultural landscapes with self-sufficient use of natural resources before the changes associated with modernization [43]. From the 1880s to the present (the 2010s), to evaluate the continuity of land dynamics, we selected the 1920s, 1940s, 1960s, 1970s, 1980s, 1990s, and 2000s (Table S1).

The present land cover is based on data from the High-Resolution Land Use and Land Cover Map with approximately $30 \mathrm{~m} \times 30 \mathrm{~m}$ resolution [42]. The acquired land use data can be continuously updated and obtained using multiple geospatial data sets, such as Landsat-8 OLI, ALOS-2/PALSAR-2, and a digital elevation model. The data shows the difference between forest and non-forest land cover in the study site with $97.4 \%$ accuracy [44]. 


\subsection{Investigating the Natural Patches Left in Urban Landscapes}

The land cover information for JAXA's maps was based on version 18.03 (around 2015: average condition of land cover for the period 2014-2016). The original 10 classifications are "Water", "Urban", "Ricepaddy", “Crops", “Grassland", "Bareland”, “Deciduous Broadleaf Forest", “Deciduous Needleleaf Forest", "Evergreen Broadleaf Forest", and "Evergreen Needleleaf Forest". This study defined the land cover thus classified as "Land cover in the 2010s".

In the High-Resolution Land Use and Land Cover Map, the data are provided in raster format consisting of grids of constant resolution. Each grid has a value as a single category of land cover. In this study, the grids classified as "Deciduous Broadleaf Forest", "Deciduous Needleleaf Forest", "Evergreen Broadleaf Forest" and "Evergreen Needleleaf Forest" were re-classified as "Forest".

We focused on "Grassland" and "Forest" land cover as urban nature in the 2010s. To clarify the natural patches left in the urban landscape, the area of land covered in the $500 \mathrm{~m}$ resolution of the FSG was compiled and hotspots in the 2010s were investigated using the Local Indicator of Spatial Autocorrelation (LISA).

The LISA is an evolution of Moran's I, a representative measure of spatial autocorrelation into a local statistic. Based on the Moran scatterplot, which classifies the analyzed districts in two dimensions - the index of their own grid (high and low) $\times$ the index of the peripheral grid (high and low)—significant spatial outliers can be detected $[45,46]$. We used this indicator to detect hotspots for "Grassland" or "Forest" land cover in the 2010s. Herein, hotspot means high-high (HH) grid, which has the value of being both high on its own grid and high on the peripheral grid. The grids match to FSGs and the area of analysis was set to 408 grids, the same as the study site. A $p$-value less than 0.05 was considered statistically significant.

We used R version 3.6.3 (The R Foundation for Statistical Computing, 2020) to analyze the collected geographic information. The spdep package was used in the analysis of LISA.

\subsection{Land Ownership of Urban Nature with Temporal Continuity of Grasslands and Forests}

We also investigated present-day management practices and land use, land ownership, and land cover since the 1880s in the identified patches of natural environments remaining in the 2010s (Figure 2). We surveyed the agencies that own and manage the urban nature in grids where the area of land cover of "Grassland" or "Forest" was significantly high in the 2010s. We referred to the Forest Plan of Ibaraki prefecture regarding forest land ownership [47]. In addition, we confirmed the status of the landowners' management in the 2010s using the municipality's green infrastructure plan [30] and management reports from each agency.

For each grid and period (Table S1), we checked how grasslands and forests, which were part of the agricultural landscape in the 1880s, were maintained prior to the 1960s and the presence or absence of further land alteration after the development of the Tsukuba Science City. We determined the temporal continuity of nature by checking the overlaps of forest or grassland sites in the 2010s and each period.

In the period since the 1970s, when agricultural landscapes were transformed by development, temporal continuity was determined by whether the sites inside the grid were approximately $50 \%$ or more built-up with topsoil alteration by checking the dataset on approximate changes every five years (Table S1). Furthermore, we obtained supplementary information on changes made to the landscape, land use, and its management since the 1940s through nine interviews with farmers, foresters, a teacher, and the president of a local construction company in three rural communities in Tsukuba City in 2019. Finally, we investigated places where "Grassland" or "Forest" was significantly high in the 2010s with temporal continuity from the 1880 s to the 2010 s. 


\subsection{Data Transformation for Land Cover Analysis}

We focused on four time periods of land cover: the 1880s as the oldest agricultural landscape, the 1960s and 1980s as the before and after for the development of the Tsukuba Science City, and the 2010s as the present (Figure 2). We created land cover maps for the four time periods using the QGIS version 3.14.16 and set the projected coordinate system to JGD2000/UTM zone 54N (EPSG: 3100) before calculating the areas for each time period.

The data from the High-Resolution Land Use and Land Cover Map were used as reference points to compare the four periods. The maps created based on the rapid survey map data, aerial photographs, topographic maps, and vegetation map were converted to approximately $30 \mathrm{~m} \times 30 \mathrm{~m}$ resolution. Finally, the change in land cover distribution and area ratio in the grids that have temporal continuity of nature environments were clarified after a comparison of the past and present.

The rapid survey maps of the study site covered 1881 (Meiji 14) to 1884 (Meiji 17). In this study, we used the land cover data from the digital maps, which were published by the National Agriculture and Food Research Organization [48]. The database consists of point-form data at $100 \mathrm{~m}$ intervals generated from the geometric corrections on the rapid survey map. We used the data corresponding to the study site. On the rapid survey maps, land cover classifications are colored. In the database, the land cover is classified within $100 \mathrm{~m}$ based on an 11-coloration categorization: "Sand", "Wetland", "Open Water", "Village", "Ricepaddy", "Crops \& Open area”, "Mulberry Field \& Tea Plantation", "Grassland \& Bareland", "Embankment \& Cliff", "Forest" and "Bamboo Forest" (Table S2). This study thus classified the 1880s as "Land cover in the 1880s".

We created a land cover map based on the 1960 topographic map. The land cover boundary was modified based on aerial photographs taken in 1961. For the 1980s, we referred to the vegetation map that had 18 land cover categories that were surveyed in 1979. However, we could not identify the land's use at the time of completion of the development, because the vegetation map recorded land cover during the development of the Tsukuba Science City. Therefore, we modified the land cover using aerial photographs taken in 1980 and 1984. The land cover classifications for each period were aggregated into the classifications defined in the topographic and vegetation maps (Table S2).

We then redefined the 1880s, 1960s, and 1980s maps classification (past classification) to match the present classification in order to compare them (Table S2). "Sand", "Wetland" and "Open Water" are re-classified as "Water". The words "Village", "Road", "Factory and industrial", and "Urban" were merged to form "Residential Area" because all of them indicate artificial, inhabited land cover. "Ricepaddy" remained "Ricepaddy". "Crops" was created from "Crops \& Open area", "Mulberry Field \& Tea Plantation", and other related classification. "Grassland" was created from merging "Bareland", "Grassland \& Bareland", and "Embankment \& Cliff" with the grassland vegetation in the 1980s. "Forest" was created from merging "Forest" and "Bamboo Forest" (Table S2).

\section{Results}

\subsection{Present Land Cover and HH Grids in "Grassland" and "Forest"}

Figure 3 shows the land cover distribution and ratio as the Tsukuba Science City (2010s). In the 2010s, "Water" accounted for 0.3\%, "Residential area" 12.9\%, "Ricepaddy" 20.4\%, "Crops" 39.3\%, "Grassland" $11.5 \%$, and "Forest" $15.6 \%$ of the study site. Figure 3 shows the distributions of the HH grids and the low-low (LL) grids of the two land covers in the 2010s. Each grid contains a clustered area of land cover that represents a higher/lower percentage of land cover than expected in its own grid and surrounding grids. In the 2010s, the HH grids had 48 sites in the "Grassland" and 34 sites in the "Forest", while the LL grids were located at 18 sites in the "Grassland" and 25 sites in the "Forest". The clustered areas named "Grassland" were concentrated in the northwestern part of the study site in the 2010s. The clustered areas named "Forest" were distributed along the northwest to east-central line of the study site in the 2010s. 


\section{Legend}
- Water
Ricepaddy
$\square$ Grassland
$\square \mathrm{HH}$
$\mathrm{HH} \quad \square$ not significant
- Residential Area
Crops
Forest
LL

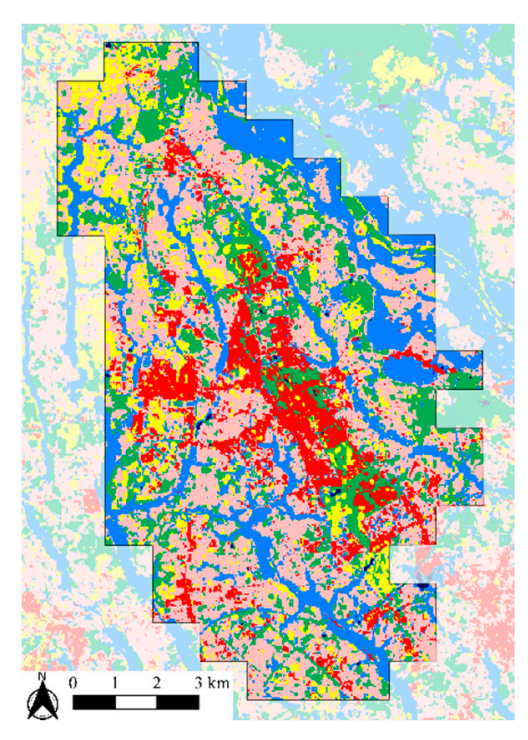

(a)

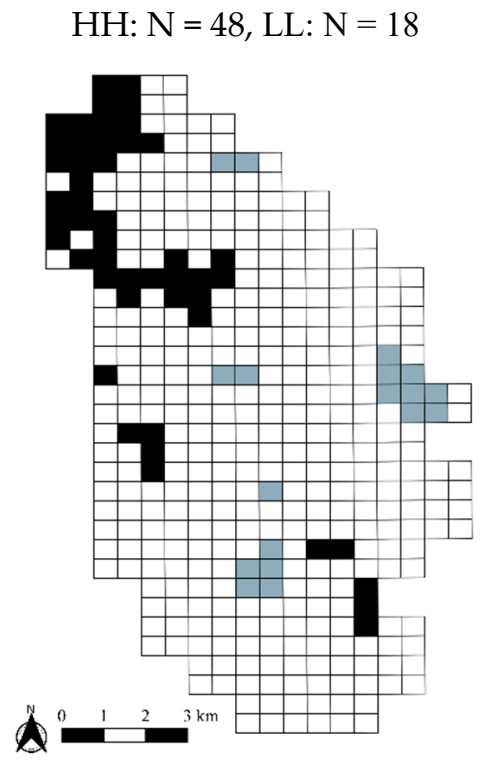

(b)

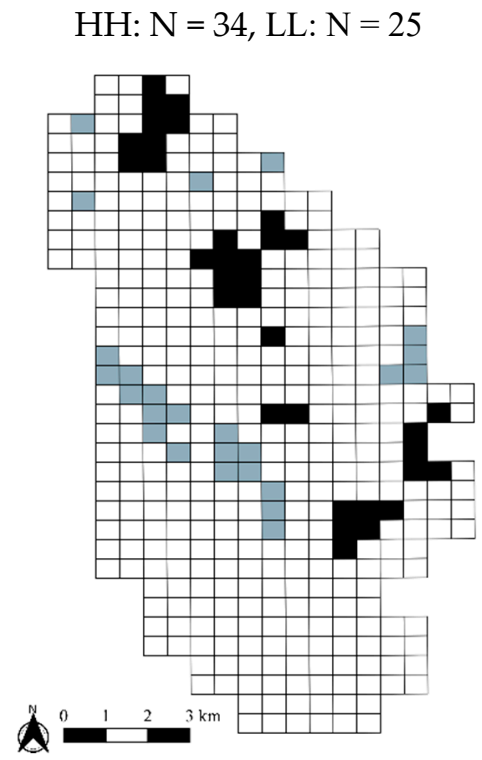

(c)

Figure 3. (a) Land cover distribution and significant high-high (HH) and low-low (LL) grids in (b) Grassland and (c) Forest in the 2010s. In (a), translucent were not included in our study site. HH means statistically significant high-high grid. LL means statistically significant low-low grid. In this study, there is no statistically significant low-high or high-low grid. A $p$-value less than 0.05 was considered statistically significant.

\subsection{Land Ownership of Natural Patches Left in HH Grids (2010s)}

Seventy-seven grids had a HH value of "Grassland" or "Forest" in the 2010s. The sum of HH in (a) and (b) in Figure 3 is 82 grids, but 5 grids have HH values for both "Grassland" and "Forest". Table 1 shows 77 grids of clustered natural patches left in urban landscapes, with categories for land ownership and management.

Forty-four grids were categorized as private land in a rural community (A D in Table 1), the largest number of all the categories. Thirty A grids are under substantial cultivation. These are all "Grassland" HH grids. "Grassland" in A is land cultivated for turf production. Tsukuba City, Ibaraki Prefecture, is the largest producer of turf in Japan after the 1970s [49]. The turf production areas could not be classified as "Crops" by JAXA database because land covered for turf production is a special type of land cover in Japan. Therefore, the natural patches here belong to rural communities and are managed by farmers. Yamamoto et al., (1992) reported that turf croplands developed after 1975 and were almost non-existent in 1970 [35]. Eight grids in B are land for timber production, with a core of forests listed in the Forest Plan. One grid in C are lands whose main purpose is to maintain the sacred landscape, with a core of shrine forests listed in the Forest Plan. In contrast, five grids in D are abandoned areas. Bush and forest vegetation in D from abandoned cultivated areas and are not shown in the Forest Plan. The vegetation map surveyed in 2002 also showed cultivated lands that were abandoned. 
Table 1. Current land ownership and their management of urban nature in the 2010s where the high-high (HH) grid of "Grassland" or "Forest" is located (77 grids).

\begin{tabular}{|c|c|c|c|}
\hline $\begin{array}{l}\text { Land Use for the Major } \\
\text { Forest/Grassland Areas } \\
\text { Located inside the Grid }\end{array}$ & $\begin{array}{l}\text { Category of Land } \\
\text { Ownership for the Major } \\
\text { Forest/Grassland Areas } \\
\text { Located inside the Grid }\end{array}$ & $\begin{array}{l}\text { Management of the Major } \\
\text { Forest/Grassland Areas } \\
\text { Located inside the Grid }\end{array}$ & $\begin{array}{l}\text { Number of Grids for } \\
\text { HH Classifications } \\
\text { of Forest/Grassland } \\
\text { in the 2010s }\end{array}$ \\
\hline A: crops & $\begin{array}{c}\text { Private land in a rural } \\
\text { community }\end{array}$ & $\begin{array}{l}\text { Managed by farmer belonging } \\
\text { to local community for their } \\
\text { farming, i.e., mainly lawn } \\
\text { production }\end{array}$ & Grassland: 30 \\
\hline B: timber forest & $\begin{array}{l}\text { Private land in a rural } \\
\text { community }\end{array}$ & $\begin{array}{l}\text { Managed by farmer belonging } \\
\text { to local community for their } \\
\text { timber production, i.e., mainly } \\
\text { fully grown conifers }\end{array}$ & Forest: 8 \\
\hline C: shrine forest & $\begin{array}{l}\text { Private land in a rural } \\
\text { community }\end{array}$ & $\begin{array}{l}\text { Including shrine forest, } \\
\text { managed by local community } \\
\text { for maintain sacred landscape }\end{array}$ & Forest: 1 \\
\hline D: abandoned area & $\begin{array}{l}\text { Private land in a rural } \\
\text { community }\end{array}$ & $\begin{array}{l}\text { Abandoned since the 2000s } \\
\text { and vegetation transitioned } \\
\text { into bushes }\end{array}$ & Forest: 5 \\
\hline $\begin{array}{l}\text { E: green space in } \\
\text { research institution }\end{array}$ & Research institution & $\begin{array}{c}\text { Managed by agency for green } \\
\text { space as a buffer to } \\
\text { urbanized area }\end{array}$ & $\begin{array}{c}\text { Forest: } 13, \\
\text { Grassland:12 } \\
\text { (include both: } 3 \text { ) }\end{array}$ \\
\hline F: golf course & Private company & $\begin{array}{l}\text { Managed by an agency for } \\
\text { recreational landscapes, e.g., } \\
\text { sustaining grassland } \\
\text { environment }\end{array}$ & Grassland: 3 \\
\hline $\begin{array}{c}\text { G: planned } \\
\text { development site }\end{array}$ & $\begin{array}{l}\text { Local government or } \\
\text { related institution }\end{array}$ & $\begin{array}{c}\text { Managed by a local } \\
\text { government (or related } \\
\text { institution) for development, } \\
\text { e.g., sustaining grassland } \\
\text { environment }\end{array}$ & $\begin{array}{l}\text { Forest: 5, Grassland: } \\
3 \text { (include both: } 2 \text { ) }\end{array}$ \\
\hline $\begin{array}{l}\text { H: public park under the } \\
\text { Urban Park Act }\end{array}$ & Local government & $\begin{array}{l}\text { Managed by a public agency } \\
\text { for recreational landscapes }\end{array}$ & Forest: 2 \\
\hline
\end{tabular}

The 22 grids in E are the second largest number of categories and were classified as research institutions. These represent the characteristics of the Tsukuba Science City, where there is a large number of research institutes with huge green space. They are managed with a mixture of "Grassland" and "Forest". Some research institutions cover multiple grids and have huge management areas. For example, the High Energy Accelerator Research Organization (HEARO) manages about 150 ha, the National Institute of Advanced Industrial Science and Technology (AIST) manages 100 ha, and the Meteorological Research Institute (MRI) manages 50 ha.

Three grids in F were classified as golf courses. They are composed of "Grassland" managed by individual agencies. In addition to research institutions, the agencies undertake management initiatives, but the purpose of their management differs when considering recreational use by visitors.

Eight grids in $\mathrm{G}$ and $\mathrm{H}$ are municipal categories. Six grids in $\mathrm{G}$ were classified as planned development sites managed by the municipalities or other relevant authorities. These are the lands that are reserved for development. Two $\mathrm{H}$ grids are classified as public parks under the Urban Park Act. These are mainly forest environments maintained as recreational areas for urban residents.

\subsection{Investigating Natural Patches Left in Urban Landscapes}

We found that natural patches, located on $25 \mathrm{HH}$ grids in the 2010s, have had temporal continuity of grassland or forest land since the 1880s (Table 2). Figure 4 shows the flow chart that identified these grids. 
Table 2. Land use and land ownership for identified 25 grids.

\begin{tabular}{|c|c|c|}
\hline $\begin{array}{c}\text { Land Use for the Major Forest/Grassland } \\
\text { Areas Located inside the Grid (Number of } \\
\text { Corresponding Grid) }\end{array}$ & $\begin{array}{l}\text { Land Ownership for the Major } \\
\text { Forest/Grassland Areas Located inside the } \\
\text { Grid (Number of Corresponding Grid) }\end{array}$ & $\begin{array}{c}\text { Moran Scatterplot } \\
\text { Classifications of } \\
\text { Forest/Grassland in the 2010s }\end{array}$ \\
\hline \multirow{3}{*}{ B: Timber forest (8) } & B-1: Private land in a rural community (4) & $\mathrm{HH}($ Forest $) \times 4$ \\
\hline & B-2: Private land in a rural community (2) & $\mathrm{HH}$ (Forest) $\times 2$ \\
\hline & B-3: Private land in a rural community (2) & $\mathrm{HH}($ Forest $) \times 2$ \\
\hline C: Shrine forest (1) & C-1: Private land in a rural community & HH(Forest) \\
\hline \multirow{3}{*}{ E: Research institution (9) } & E-1: University of Tsukuba (5) & $\begin{array}{l}\text { HH(Forest, Grassland }), \\
\text { HH(Forest }) \times 4\end{array}$ \\
\hline & $\begin{array}{l}\text { E-2: National Institute of Advanced } \\
\text { Industrial Science and Technology } \\
\text { (AIST) (2) }\end{array}$ & $\mathrm{HH}($ Forest $) \times 2$ \\
\hline & $\begin{array}{l}\text { E-3: Meteorological Research Institute } \\
\text { (MRI) (2) }\end{array}$ & $\begin{array}{l}\text { HH(Forest, Grassland), } \\
\text { HH(Grassland) }\end{array}$ \\
\hline F: Golf course (3) & $\begin{array}{l}\text { F-1: Kasumigaura International Golf } \\
\text { Course (3) }\end{array}$ & $\mathrm{HH}($ Grassland $) \times 3$ \\
\hline G: Planned development site (4) & $\begin{array}{l}\text { G-1: Tsukuba City, land purchased for the } \\
\text { new public park but canceled and not } \\
\text { developed (4) }\end{array}$ & $\begin{array}{l}\mathrm{HH}(\text { Forest, Grassland }) \times 2, \\
\mathrm{HH}(\text { Forest }) \times 2\end{array}$ \\
\hline
\end{tabular}

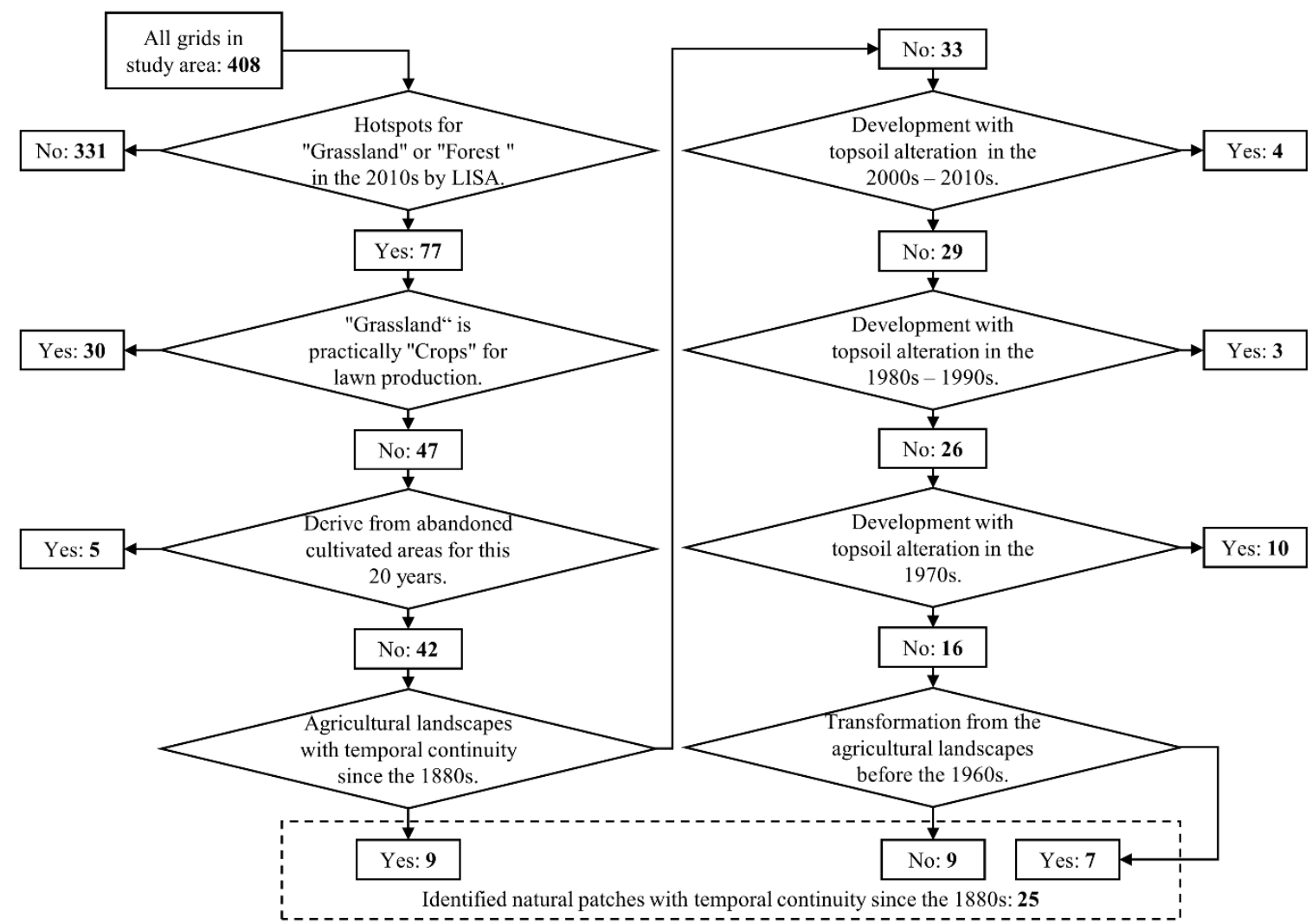

Figure 4. Flow chart for identifying the natural patches left in urban landscapes with temporal continuity since the 1880 s.

By analyzing hotspots with LISA and excluding misclassification of grassland land cover in turf-producing areas, we classified the natural environments into 47 grids. Further, after analyzing the Forest Plan, we found five grids with rural community forests that had been generated by the abandonment of crop fields in the past 20 years and were excluded from the continuum. At the same time, we classified nine grids of rural community forests that have persisted as part of the agricultural landscape since the 1880s. The natural environment in 33 grids had experienced at least 1 developmental change from being agricultural landscapes due to the development of the Tsukuba Science City. Four of these grids were excluded from continuity, because they experienced 
topsoil alteration during the 2000s-2010s. Three grids were also excluded for the same reason during the 1980s-1990s.

In addition, 10 grids were excluded after the first development of the Tsukuba Science City in the 1970s. We found that almost all "Forest" or "Grassland" lands in these 10 grids were derived from plantations after topsoil alteration in the 1970s. However, the location of natural environments in the 16 grids remained the original "Forest" or "Grassland" through the development. Note that they include seven grids of transformation from the agricultural landscapes before the 1960s, although the original "Grassland" land cover was utilized as the golf course and weather observation facility. In particular, the grassland in the MRI, which was established as a result of the expansion and development of the Aerological Observatory established in the 1920s, has been reported by biodiversity monitoring in collaboration with the public and researchers in the 2010s [50].

\subsection{Characteristics of the Patches of Natural Environments in the HH Grid}

Table 2 shows the current land use and land ownership for the extracted 25 grids. Figure 5 shows the distribution of the identified 25 grids in the Tsukuba Science City. Figures 6-8 show changes in land cover types for each land ownership.

Nine grids were extracted from the $B$ and $C$ land use category that belong to three rural communities (B-1, B-2, and B-3; note that the B-3 community matches those in C-1). We found an overlap of the forest in the 2010s and those from each period since the 1880s (Figure 6a). Figure $6 \mathrm{~b}$ shows that part of the "Forest" remained unchanged through all periods. The major changes in land cover type (more than $10 \%$ change in the area) are seen in the change from "Forest" to "Residential area" (11.3\%) between the 1960s and 1980s and from "Residential area" to "Crops" (10.8\%) between the 1980s and 2010s. In addition, 5.3\% of the land changed from "Residential area" to "Forest" between the 1980s and 2010s. We also found that the "Grassland" in the 1980s (6.2\%) and 2010s (9.2\%) were mainly derived from the "Forest" of the 1960s (3.5\%) and "Crops" in the 1980s (3.5\%), while "Grassland" accounted for less than $1 \%$ in the 1880 s and 1960 s.

Nine grids were extracted from the E category: research institutions. Five E-1 grids overlapped with the site of the University of Tsukuba. One of the E-1 grids is located at a distance from the others. The E-2 and E-3 grids are in contact with each other. Forest in the two E-2 girds of the 2010s mainly overlapped with the site of the AIST. In addition, forest and grassland in the two E-3 girds of 2010s mainly overlapped with the site of the MRI.

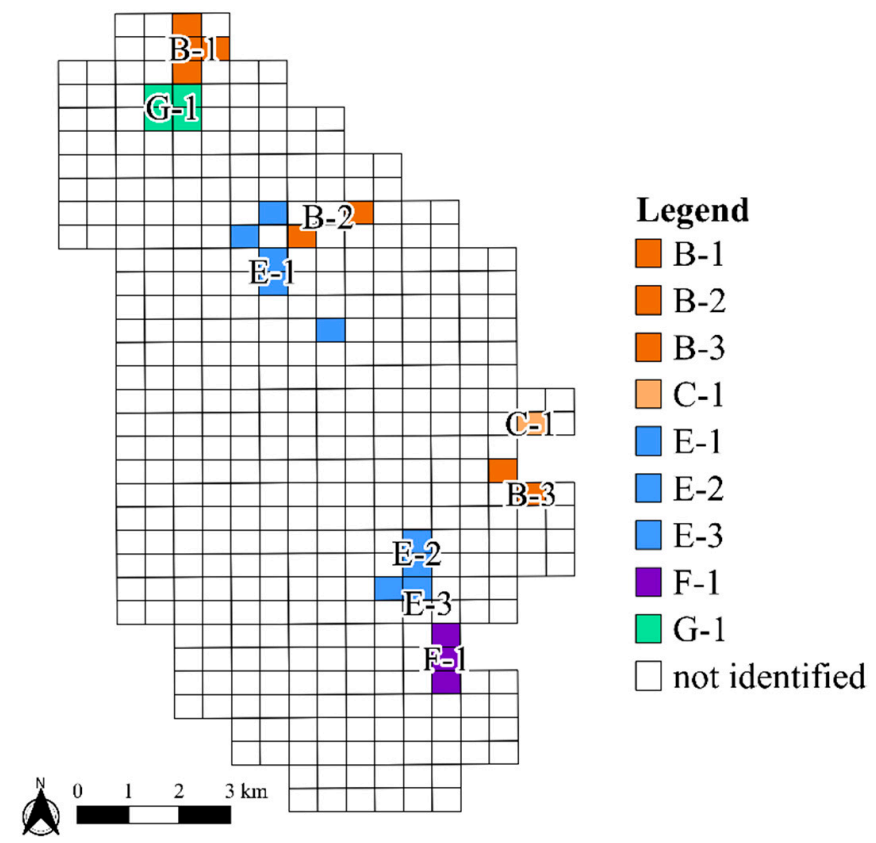

Figure 5. Distribution of the identified 25 grids in the Tsukuba Science City. 


\section{Legend}

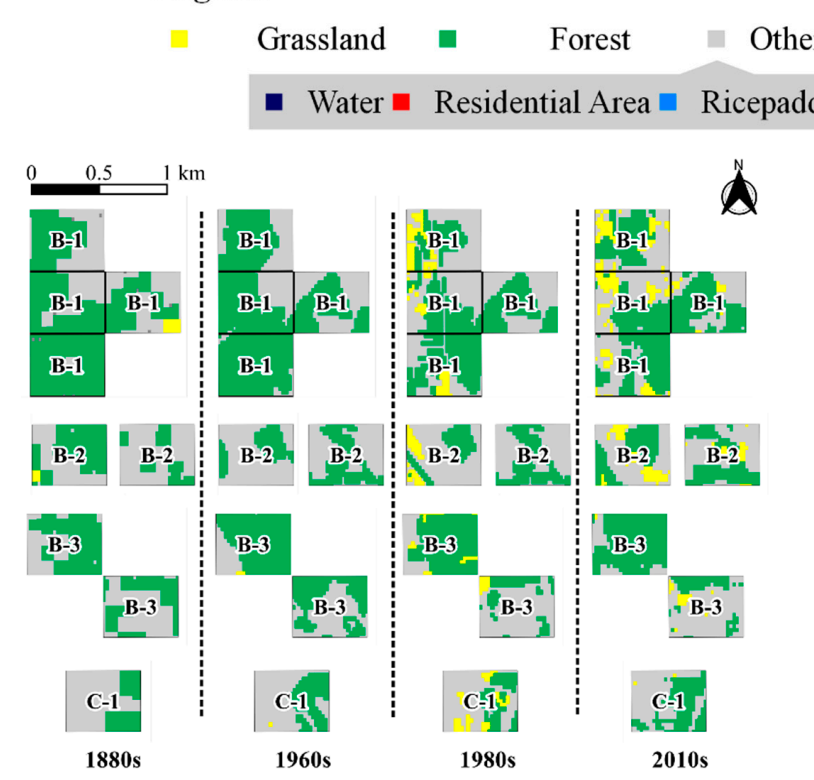

(a)

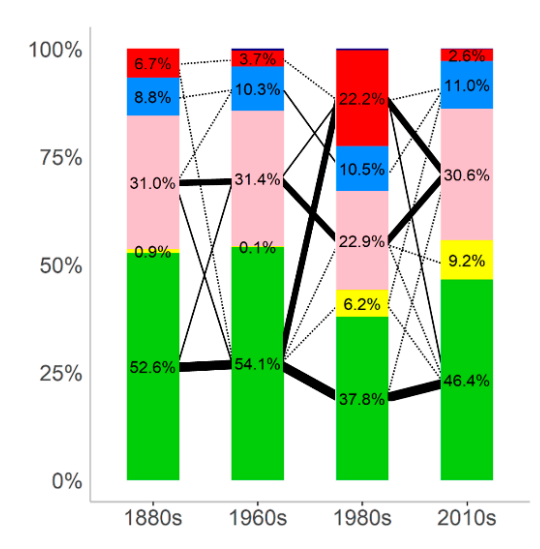

(b)

Figure 6. The time series land cover map and changes in land cover types in the grids that belong to three rural communities. (a) shows the land cover map between the 1880s and 2010s focused on the natural environments (Forest and Grassland). (b) shows the changes in land cover types between the 1880s and 2010s. The value in each bar represents the percentage (\%) of each land cover type. The connecting line between two bars indicates the change in land cover type through the periods. The thickness of the line corresponds to the proportion of the changed area with respect to the grids shown in (a). The line was omitted if the proportion is less than $2.5 \%$.

\section{Legend}

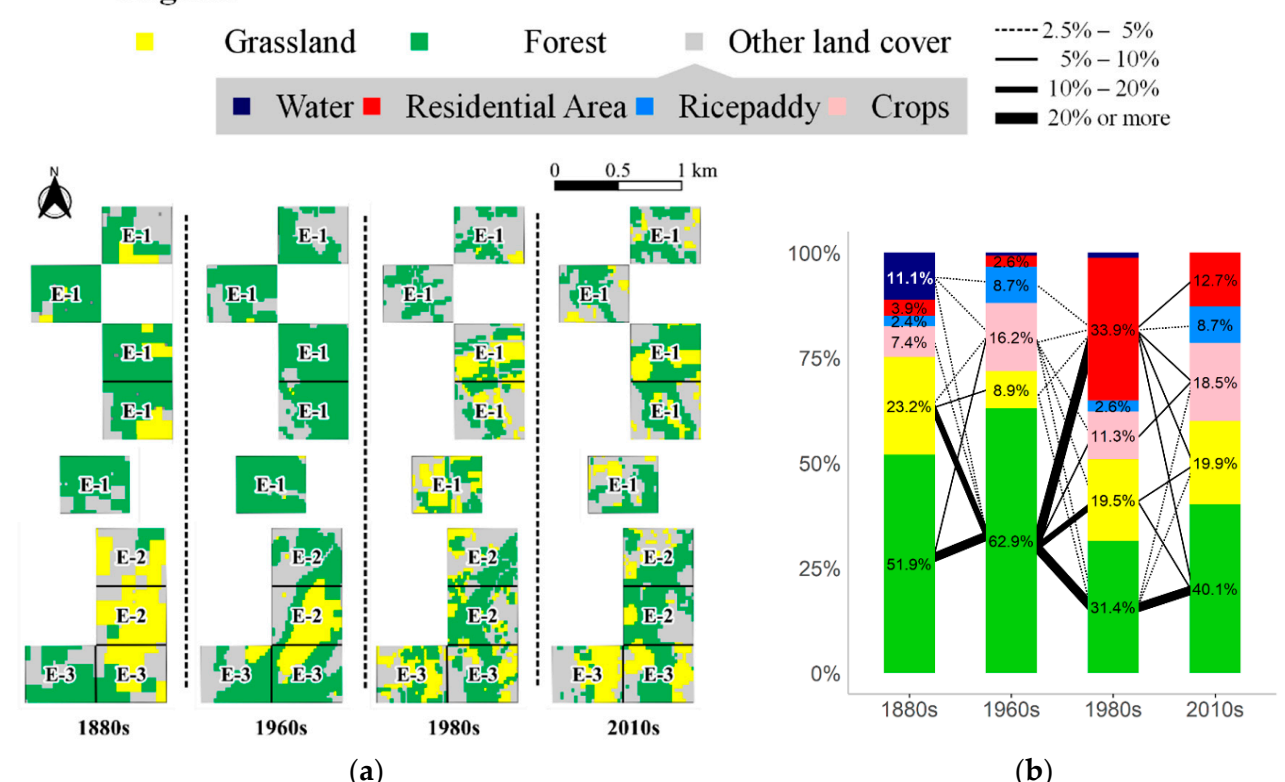

Figure 7. The time series land cover map and changes in land cover types in the grids that belong to research institutions. (a) shows the land cover map between the 1880s and 2010s focused on the natural environments (Forest and Grassland). (b) shows the changes in land cover types between the 1880s and 2010s. The value in each bar represents the percentage (\%) of each land cover type. The connecting line between two bars indicates the change in land cover type through the periods. The thickness of the line corresponds to the proportion of the changed area with respect to the grids shown in (a). The line was omitted if the proportion is less than $2.5 \%$. 


\section{Legend}

\begin{tabular}{|c|c|c|}
\hline Grassland & Forest & Other land cover \\
\hline - Water & Residential Area & Ricepaddy \\
\hline
\end{tabular}

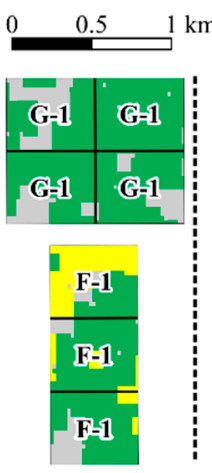

$1880 \mathrm{~s}$

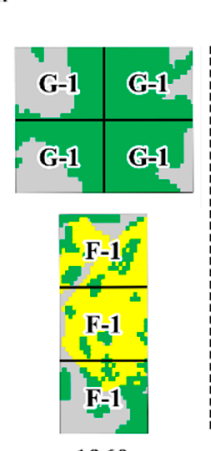

$1960 s$

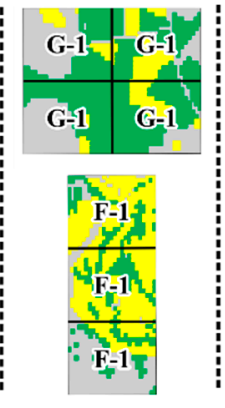

$1980 s$

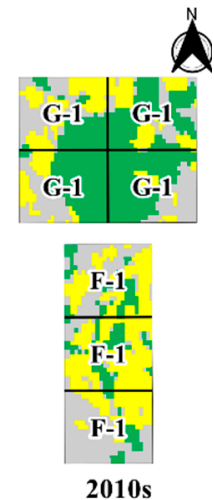

$2010 s$

(a)

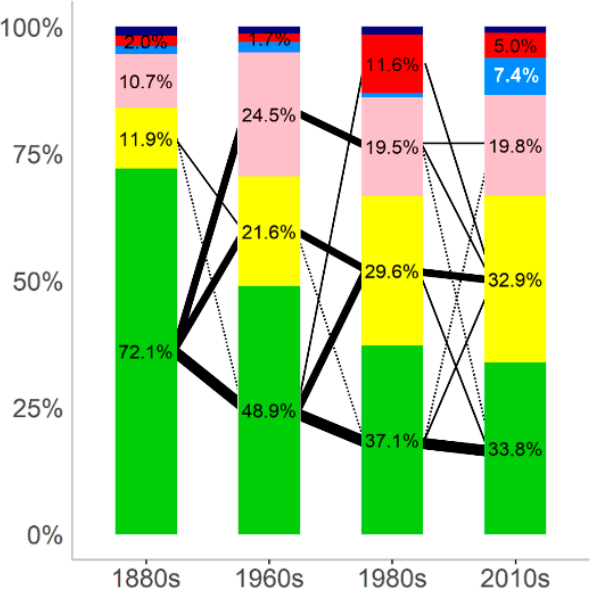

(b)

Figure 8. The time series land cover map and changes in land cover types in the grids that belong to the golf courses and planned development sites. (a) shows the land cover map between the 1880s and 2010s focused on the natural environments (Forest and Grassland). (b) shows the changes in land cover types between the 1880s and 2010s. The value in each bar represents the percentage (\%) of each land cover type. The connecting line between two bars indicates the change in land cover type through the periods. The thickness of the line corresponds to the proportion of the changed area with respect to the grids shown in (a). The line was omitted if the proportion is less than $2.5 \%$.

We found temporal continuity of forest (also grassland in three grids) since the 1880s (Figure 7a). Figure $7 \mathrm{~b}$ shows that part of the "Forest" remained unchanged through all periods, although $20.7 \%$ of the "Forest" changed to "Residential area" in the 1980s. The major changes in land cover type (more than 10\% change in the area) are also seen in the change from "Grassland" to "Forest" (13.7\%) between the 1880s and 1960s and from "Forest" to "Grassland" (12.3\%) between the 1960s and 1980s. Furthermore, 9.6\% of the land changed from "Residential area" to "Forest" between the 1980s and 2010s. We found that parts of the "Grassland" remained unchanged, especially those in the E-3 grids (Figure 6a,b).

Four grids were extracted from the G category, which are the planned sites for development. G-1 grids have existed as proposed sites for development since the 1970s and are denoted as HH grids for "Forest" including two "Grassland". In addition, three F-1 grids overlapped with the site of the Kasumigaura International Golf Course. All F-1 grids consisted of HH grids for "Grassland".

We found the temporal continuity of "Forest" in G-1 since the 1880s (Figure 8a). Figure 8b shows that part of the "Forest" remained unchanged through all periods, although a certain percentage changed from "Forest" to "Grassland" in each period (1880s-1960s: 15.4\%; 1960s-1980s: 10.0\%; 1980s-2010s: 7.7\%). The major changes in land cover type (more than 10\% change in the area) are also limited to changes from "Forest" to "Crops" (13.7\%) between the 1880s and 1960s. Most of the "Grassland" have been handed over to the next period since the 1960s for F-1 and the 1980s for G-1.

The increase in "Residential area" in the 1980s indicates an increase in human-made land uses, such as for roads and facilities, that were not present in rural settlements. These increases were supported by the conversion of rural forests and grasslands. In contrast, in the 2010s, some of the land marked "Residential area" was changed to "Crops" and "Forest". It is assumed that the misclassification from "Residential area" to "Forest" based on satellite imagery occurred due to changes 
of what was once artificial land cover in the 1980s into mature street trees, green belts, and "Urban and residential districts with many trees" in the 2010s.

In particular, we found that the grassland land cover has remained consistent since the 1880s in the MRI (E-3). However, those at the University of Tsukuba (E-1) and Kasumigaura International Golf Course (F-1) in the 2010s were derived from "Forest". During the interviews, several farmers said the pine forests incorporated into some research institutions were originally agricultural landscapes with grassland-like environments, sparse vegetation, and a clear forest floor for natural resource use from the 1940s to the 1960s. They also said that the remaining pine forests in the community had been underused for a long period of time since the 1960s and changed to dense vegetation around the 1990s, whereas the pine forests belonging to research institutions survived by themselves.

\section{Discussion}

As pointed out in previous research, the past landscape of the study site is a typical traditional agricultural landscape of Japan [31-34]. In other words, the landscape consists of rice paddies, crops, residential areas, ponds, forests, and grasslands spread out in units of rural communities. The rice paddies were located along a small stream flowing through the uplands. The crops, residential areas and ponds were located on higher ground than the ricepaddy. The forests and grasslands were located on higher ground leading to the adjacent community. From the 1880s to 1960s, urbanized areas were located in Tsuchiura City, outside the present-day Tsukuba City, and in Yatabe, outside present-day Tsukuba Science City. The land cover of the "Residential area" was limited to those of rural communities for this study before the 1960s.

Previous research has pointed out that if rural ricepaddies and crops were maintained after the 1950s, then rural forests were also maintained despite being surrounded by urban areas [27,31]. The remnant forest patches of rural communities as shown in Figure 6 were able to be maintained to the present day because rural communities themselves were maintained despite the developments in their surroundings. Indeed, rural communities have maintained forest patches, such as timber and shrine forests, despite the surrounding urbanization. This aspect demonstrates the importance of conserving the agricultural structure of these communities.

The distribution of each type of land cover, land use, and land ownership from the 1960s to 1980s reflects changes caused by the urbanization of rural communities. Figures 6-8 show the transformation of rural forests to urbanized areas. We found that following the development of the 1970s, institutions and municipalities have replaced large areas of grassland and forest surrounding rural communities. Urban nature has been managed as green spaces by individual institutions and municipalities for about the past 40 years after the development on the basis of agricultural landscape management for at least 90 years. We thus suggest that institutions and municipalities prioritize the conservation of large-scale urban green space patches, such as grasslands and forests, with the intention of maintaining these environments for 100 years or more.

One of the most important areas for the conservation strategy in the study site is the urban nature in the research institutions. Takahashi revealed changes in land use and land ownership as a result of the development of the Tsukuba Science City by analyzing land ownership transfers between 1959 and 1976 in three rural communities that were at the core of the development [51]. According to the study, about 70\% of the 2093 land ownership transfers between 1959 and 1976 were due to land purchase by public agencies from local residents for the purpose of building research institutions, housing complexes and roads. Before 1968, when the development of the Tsukuba Science City began, there was only a slight shift in land ownership, but by 1972, a large amount of land had been purchased by public agencies, mainly in the land categories "Woodland" and "Uncultivated Field". From these reports, it can be assumed that urban nature in research institutions not only form a large number of clustered areas of the natural environment, but have also replaced much of the human-modified landscapes of past agricultural landscapes. 
The urban nature of each research institution is managed by just one landowner. Thus, the management strategy of the areas is relatively easy to formulate, although urban nature is affected by various human activities derived from complicated land ownership [9,10]. Moreover, since research institutions have high public interest, sustainability is secured through land management. In contrast, because these research institutions are managed as green spaces, biodiversity conservation measures are not usually implemented [9]. Previous research has pointed out that urban nature, which is prioritized for conservation strategies, are not nature-protected areas but protected areas for residents' use for recreation and cultural heritage [52]. Some research institutions have developed their own green space management plans that consider biodiversity conservation [50,53-55]. In particular, HEARO and MRI report that endangered species inhabiting the agricultural landscape are found in their management areas, and conservation activities are carried out in collaboration with civil society organizations and communities. This study identified urban green space patches surrounding that were approximately 130 years old at the University of Tsukuba, AIST, and MRI. Those institutions should form the core of a conservation network with other institutions.

Golf courses and planned development sites are equally important, as they have transformed the natural environments of agricultural landscapes into nature-based land cover without causing topographic changes. However, similar to research institutions, biodiversity-friendly management is not always implemented. In addition, similar to forests in rural communities, there is no guarantee that management will continue. In particular, planned development sites are likely to disappear within a few years. In recent years, fortunately, governments, citizens, and researchers have become increasingly interested in urban green infrastructure that provides a variety of ecosystem services. We suggest that urgent biodiversity monitoring for detecting accurate biota should be conducted in these areas in cooperation with managers, external experts, and the public because they have high potential as residual human-modified landscapes. Placing a valuing on them is necessary to incentivize sustaining their natural environments to implement conservation strategies.

A number of studies point out that biodiversity richness was affected by decades of habitat connectivity, particularly in human-maintained grasslands, which are symbolic human-modified landscapes [15,56-60]. It is necessary to prioritize certain conservation goals by investigating historical land cover transitions and maintaining continuity, including in the context of urban nature $[6,61]$. Therefore, the urban green space patches that replaced grassland-like environments that were under the control of rural communities are important as a remnant for human-modified landscapes.

In Japan, grassland ecosystems have been greatly affected by the decline in natural resource usage because they have been maintained under human-made influence. In addition, it is pointed out that the forest ecosystem as a traditional agricultural landscape in Japan is close to grasslands because the vegetation is too sparse and mainly composed of pine trees and used resources collected from the forest floor [31,43,62]. In fact, an ethnographic study conducted in 1976 at the study site showed that forests were used to get grassland plants in the predevelopment agricultural landscape [36]. The results of the interviews also suggest that the forests as an agricultural landscape before the 1960s had the characteristics of a grassland environment. Therefore, even if the clustered areas were classified as "Forest" in the 1880s, there can be essential cases of grassland biodiversity [61]. Because grasslands in Japan cannot be maintained without continued management, the conservation of these grasslands, such as the grasslands in the HEARO, may be highly valuable even though their top soils were modified decades ago. Indeed, they may be a refuge for grassland biodiversity. In the future, it will be necessary to assess the biodiversity of urban grasslands, in addition to the investigated hotspots.

Previous research found that old grasslands (maintained at least 162 years) at ski runs used recreationally and replaced from agricultural landscapes have high conservation priority because they had higher plant species diversity, higher richness of grassland-dependent endangered plant species, and unique species compositions [56]. This study suggests that various lands can replace rural grassland environments besides golf courses. The results of this study provide an indicator for 
investigating areas that are expected to have high biodiversity in grassland environments, and help with the identification of biodiversity monitoring sites.

In contrast, it is questionable whether human-modified landscapes have been maintained since the 1970s. In Japan, it is expected that there will be a population decline in rural villages, the accompanying concentration of population in urban areas, and the disappearance and simplification of mosaic agricultural landscapes such as forests, grasslands, ricepaddy, and crops $[63,64]$. A previous study reported that it is difficult to conserve traditional agricultural landscapes without using natural resources due to 30 years of vegetation succession in the protected area established near the study site in 1990 [65]. Abandoned farming lands were also identified as clustered forest patches in the 2010s. In addition, satellite imagery from the 2010s detected land that had changed from "Residential area" to "Forest" due to the growth of the greenbelt, street trees, and building greenery. Previous research revealed that at the study site, green spaces have turned into jungles with an overwhelming amount of vegetation after more than 30 years of tree management without adequate thinning [22-24]. It should be considered that there would have been a transition from human-made landscapes to more wilderness landscapes through vegetation succession, even if the natural environment remained after the surrounding urbanization in the same space. In the future, researchers must assess the present-day needs of individual landowners of natural environments identified in this study and the sustainability of these landscapes.

The pattern of replacement of forests and grasslands to residential areas is typical at the scale of the prefectures surrounding the study site $[27,31,61]$. Generally, in Japan's metropolitan areas, urban sprawl aggravated the farming environment. As the natural environment has been preserved in accordance with urban planning from the beginning of its development $[23,28,29]$, this study in the Tsukuba Science City may be an exceptional case in Japan. Previous research considered Tsukuba as equal to other planned cities, and science development emerged during the 1950s, for instance, with Brasilia and Akademgorodok [23]. Therefore, the study results can be applied to future urban development and urban green planning through the systematic arrangement of urban green space. Simultaneously, a previous research indicated "planning blight" in Tsukuba, which applied a well-tended and well-planned policy; now, however, decades have passed since development [23]. Our results suggest that as time passes, policy in planned cities needs to change according to the current context of green space management.

\section{Conclusions}

In this study, we discussed natural patches in urban landscapes, clarified actual management practices in identified patches, and noted changes in land ownership and land cover during the last 130 years in the Tsukuba Science City, Japan. We argued that the urban natural environment, which has been managed by individual institutions, represented by research institutions since the 1970s, is important as human-modified landscapes that replace past agricultural landscapes. Urban landscape planning must employ a new conceptual framework that incorporates different ways lands have managed to survive over multiple decades. Finally, we argued that institutions and municipalities must prioritize lands for conservation with the intention of maintaining these environments for 100 years or more. Urban planners, not only for newly developing cities but also for developed cities, would be able to apply policy implications through systematic arrangement for diverse conservation strategies to maintain urban green space patches. Further investigation is required to elucidate these remnant green patches' ecosystem services.

Supplementary Materials: The following are available online at http://www.mdpi.com/2073-445X/9/11/425/s1; Table S1: Data source and period; Table S2: Correspondence between the data underlying past and present land cover classifications.

Funding: This work was partly supported by the Research Grant of the Mt. Tsukuba Area Japanese Geopark and the Waseda University Grant for Special Research Projects (Project number: 2020C-687).

Acknowledgments: We would like to thank Taiichi Ito, Motoshi Hiratsukua, Toshiya Matsuura, Kazunari Yamaki, and Yui Ogawa for their help in improving this paper. 
Conflicts of Interest: The author declares no conflict of interest. The funders had no role in the design of the study, or in the collection, analyses, and interpretation of data. Nor did they influence the writing of the manuscript or the decision to publish the results.

\section{References}

1. Worboys, G. Concept, purpose and challenges. In Protected Area Governance and Management; Worboys, G.L., Lockwood, M., Kothari, A., Feary, S., Pulsford, I., Eds.; ANU Press: Canberra, Australia, 2015; pp. 9-42.

2. Benton, T.G. Managing farming's footprint on biodiversity. Science 2007, 315, 341-342. [CrossRef]

3. Swift, M.J.; Izac, A.M.N.; van Noordwijk, M. Biodiversity and ecosystem services in agricultural landscapes-Are we asking the right questions? Agric. Ecosyst. Environ. 2004, 104, 113-134. [CrossRef]

4. Green, R.E.; Cornell, S.J.; Scharlemann, J.P.W.; Balmford, A. Farming and the fate of wild nature. Science 2005, 307, 550-555. [CrossRef]

5. Tilman, D. Global Environmental Impacts of Agricultural Expansion: The Need for Sustainable and Efficient Practices. In Proceedings of the National Academy of Sciences, San Diego, CA, USA, 5-6 December 1998; pp. 5995-6000.

6. Antrop, M. Why landscapes of the past are important for the future. Landsc. Urban Plan. 2005, 70, 21-34. [CrossRef]

7. Harrop, S.R. Traditional agricultural landscapes as protected areas in international law and policy. Agric. Ecosyst. Environ. 2007, 121, 296-307. [CrossRef]

8. Kumar, B.M.; Takeuchi, K. Agroforestry in the Western Ghats of peninsular India and the satoyama landscapes of Japan: A comparison of two sustainable land use systems. Sustain. Sci. 2009, 4, 215-232. [CrossRef]

9. Aronson, M.F.J.; Lepczyk, C.A.; Evans, K.L.; Goddard, M.A.; Lerman, S.B.; MacIvor, J.S.; Nilon, C.H.; Vargo, T. Biodiversity in the city: Key challenges for urban green space management. Front. Ecol. Environ. 2017, 15, 189-196. [CrossRef]

10. Alvey, A.A. Promoting and preserving biodiversity in the urban forest. Urban For. Urban Green. 2006, 5, 195-201. [CrossRef]

11. Sirakaya, A.; Cliquet, A.; Harris, J. Ecosystem services in cities: Towards the international legal protection of ecosystem services in urban environments. Ecosyst. Serv. 2018, 29, 205-212. [CrossRef]

12. LaPoint, S.; Balkenhol, N.; Hale, J.; Sadler, J.; van der Ree, R. Ecological connectivity research in urban areas. Funct. Ecol. 2015, 29, 868-878. [CrossRef]

13. Shwartz, A.; Turbé, A.; Julliard, R.; Simon, L.; Prévot, A.C. Outstanding challenges for urban conservation research and action. Glob. Environ. Chang. 2014, 28, 39-49. [CrossRef]

14. Cortinovis, C.; Geneletti, D. Ecosystem services in urban plans: What is there, and what is still needed for better decisions. Land Use Policy 2018, 70, 298-312. [CrossRef]

15. Saito, M.U.; Furukawa, T.; Koyanagi, T.F. Time-delayed response of Japanese hare distribution to landscape change along an urban gradient. J. Mammal. 2016, 97, 1451-1460. [CrossRef]

16. Soga, M.; Koike, S. Life-history traits affect vulnerability of butterflies to habitat fragmentation in urban remnant forests. Ecoscience 2012, 19, 11-20. [CrossRef]

17. Le Roux, D.S.; Ikin, K.; Lindenmayer, D.B.; Blanchard, W.; Manning, A.D.; Gibbons, P. Reduced availability of habitat structures in urban landscapes: Implications for policy and practice. Landsc. Urban Plan. 2014, 125, 57-64. [CrossRef]

18. Liu, S.; Du, W.; Su, H.; Wang, S.; Guan, Q. Quantifying impacts of land-use/cover change on urban vegetation gross primary production: A case study of Wuhan, China. Sustainability 2018, 10, 714. [CrossRef]

19. Guan, X.; Shen, H.; Li, X.; Gan, W.; Zhang, L. A long-term and comprehensive assessment of the urbanization-induced impacts on vegetation net primary productivity. Sci. Total. Environ. 2019, 669, 342-352. [CrossRef] [PubMed]

20. Xi, Y.; Thinh, N.X.; Li, C. Spatio-temporal variation analysis of landscape pattern response to land use change from 1985 to 2015 in Xuzhou City, China. Sustainability 2018, 10, 4287. [CrossRef]

21. Furberg, D.; Ban, Y.; Mörtberg, U. Monitoring urban green infrastructure changes and impact on habitat connectivity using high-resolution satellite data. Remote Sens. 2020, 12, 3072. [CrossRef]

22. Hino, K.; Fujii, S.; Yamamoto, S.; Watanabe, S. The Living Environment in Tsukuba Science City, Japan: Progress and Current Challenges. In Proceedings of the 16th International Planning History Society, St. Augustine, FL, USA, 20-23 July 2014; pp. 480-493. 
23. Miao, J.T. Knowledge economy challenges for the post-developmental state: Tsukuba Science City as an in-between place. Town Plan. Rev. 2018, 89, 61-84. [CrossRef]

24. Yokohari, M.; Amemiya, M.; Amati, M. The history and future directions of greenways in Japanese New Towns. Landsc. Urban Plan. 2006, 76, 210-222. [CrossRef]

25. Shirakawabe, T. The theory of mountain and field disputes in the Genroku-era (1688-1704) at the rural communities. Bull. Tokg. Inst. Hist. For. 1990, 24, 41-87. (In Japanese)

26. Kawamata, T. The firewood production area of Ibaraki Prefecture in early-mid Meiji era: Through the analysis of historical documents of firewood wholesaler. J. Ibar. Geogr. Soc. 2014, 15, 1-25. (In Japanese)

27. Sprague, D.S.; Iwasaki, N. Time series GIS analysis of rural land use change in southern Ibaraki Prefecture with historical maps starting with rapid survey maps. J. Jpn. Inst. Landsc. Arch. 2009, 72, $623-626$. (In Japanese) [CrossRef]

28. Bloom, J.L.; Asano, S. Tsukuba Science City: Japan tries planned innovation. Science 1981, 212, $1239-1247$. [CrossRef]

29. Eizen Association. Project Records on the Government Urban Planning in the Tsukuba Science City; Eizen Association: Tokyo, Japan, 1981. (In Japanese)

30. Parks and Facilities Division, Construction Department, Tsukuba City. Tsukuba City Greening Basic Plan (Revised Edition); Parks and Facilities Division, Construction Department, Tsukuba City: Tsukuba, Japan, 2016. (In Japanese)

31. Yamamoto, S. Studies on the effect of changes in rural landscape structure on secondary forest plants in Japanese rural areas. Bull. Natl. Inst. Agro-Environ. Sci. 2001, 20, 1-105. (In Japanese)

32. Sprague, D.S.; Goto, T.; Moriyama, H. GIS analysis using the rapid survey map of traditional agricultural land use in the early Meiji era. J. Jpn. Inst. Landsc. Arch. 2000, 63, 771-774. (In Japanese) [CrossRef]

33. Sprague, D.S. Land-use configuration under traditional agriculture in the Kanto Plain, Japan: A historical GIS analysis. Int. J. Geogr. Inf. Sci. 2013, 27, 68-91. [CrossRef]

34. Sprague, D.S. Monitoring Habitat Change in Japanese Agricultural Systems. In Proceedings of the Agriculture and Biodiversity: Developing Indicators for Policy Analysis, Zurich, Switzerland, 5-8 November 2001; pp. 168-173.

35. Yamamoto, S.; Takahashi, N.; Nakagawa, T.; Hashimoto, Y.; Haga, H.; Kashima, H.; Sobajima, Y. Land use in Tsukuba Science City. Univ. Tsuk. Reg. Surv. Rep. 1992, 14, 1-8. (In Japanese)

36. Yamamoto, S.; Masai, Y.; Sasaki, H.; Takahashi, N.; Ishi, H.; Akahane, T.; Kobayashi, K. The transformation of the Tsukuba Science City and its surrounding areas. Tsuk. Environ. Stud. 1976, 1, 88-102. (In Japanese)

37. National Land Information Division Densely Inhabited District Data. Available online: https://nlftp.mlit.go. jp/ksj/gml/datalist/KsjTmplt-A16-v2_3.html (accessed on 16 August 2019). (In Japanese)

38. Statistics of Japan the Fourth Standard Grid of Japan. Available online: https://www.e-stat.go.jp/gis/statmapsearch page $=1 \&$ type $=2 \&$ aggregateUnitForBoundary $=$ H\&prefCode $=08 \&$ coordsys $=2 \&$ format $=$ shape (accessed on 24 August 2020). (In Japanese)

39. Geospatial Information Authority of Japan: The Source of GSI Maps. Available online: https://github.com/ gsi-cyberjapan/gsimaps (accessed on 8 September 2020). (In Japanese)

40. Ministry of Environment. The 2nd National Surveys on the Natural Environment Vegetation Map. Available online: http://www.biodic.go.jp/trialSystem/vg/vg.html (accessed on 21 November 2019). (In Japanese)

41. Ministry of Environment. The 6th and 7th National Surveys on the Natural Environment Vegetation Map. Available online: http://www.biodic.go.jp/trialSystem/vg/vg.html (accessed on 21 November 2019). (In Japanese)

42. Japan Aerospace Exploration Agency High-Resolution Land Use and Land Cover Map of Japan (2014-2016) (Version 18.03). Available online: https://www.eorc.jaxa.jp/ALOS/en/lulc/lulc_index_v1803.htm (accessed on 2 July 2019). (In Japanese)

43. Sprague, D.S.; Iwasaki, N. The Rapid Survey Maps: Japan's First Modern Topographic Maps and the GIS Analysis of Historical Land Use in the Kanto Plain. In Proceedings of the International Research Symposium Proceedings, Kyoto, Japan, 30 June 2006; pp. 165-177.

44. Tsutsumida, N.; Nagai, S.; Rodríguez-Veiga, P.; Katagi, J.; Nasahara, K.; Tadono, T. Mapping Spatial Accuracy of Forest Type Classification in JAXA's High-Resolution Land Use and Land Cover Map. In Proceedings of the Joint Workshop “Multidisciplinary Remote Sensing for Environmental Monitoring”, Kyoto, Japan, 12-14 March 2019; pp. 57-63.

45. Cliff, A.D.; Ord, J.K. Spatial Processes: Models E Applications; Pion: London, UK, 1981.

46. Anselin, L. Local indicators of spatial association-LISA. Geogr. Anal. 2010, 27, 93-115. [CrossRef] 
47. Ibaraki Prefecture Forest Plan, Ibaraki Prefecture. Available online: https://www.pref.ibaraki.jp/kikaku/joho/ it/opendata/od-01/0607002_20190401_sinrinbo.html (accessed on 19 September 2019). (In Japanese)

48. The National Agriculture and Food Research Organization Historical Agro-Environment Browsing System Land Use/Cover Data. Available online: https://github.com/HabsNiaes/habs_luccdb (accessed on 2 September 2019). (In Japanese)

49. Onodera, A.; Morimoto, T.; Kamikihara, S. Regional development of turf cultivation in Tsukuba City. Univ. Tsuk. Reg. Surv. Rep. 1992, 14, 75-94. (In Japanese)

50. The Nature Conservation Society of Japan The First Session of Conservation for the "Chigusa-ga-hara to Next Generation Project" Was Held. Available online: https://www.nacsj.or.jp/archive/2012/08/1535/ (accessed on 9 September 2020). (In Japanese)

51. Takahashi, N.; Ishi, H.; Akahane, T.; Kobayashi, K. Land use and land ownership changes in the Tsukuba Science City. Tsuk. Environ. Stud. 1978, 3, 20-25. (In Japanese)

52. Kasada, M.; Matsuba, M.; Miyashita, T. Human interest meets biodiversity hotspots: A new systematic approach for urban ecosystem conservation. PLoS ONE 2017, 12, e0172670. [CrossRef]

53. Campus Planning Division, Facilities Committee, Facilities Department, University of Tsukuba. Campus Renewal Master Plan of TUV; University of Tsukuba: Tsukuba, Japan, 2002. (In Japanese)

54. Environmental Management Committee, National Institute for Environmental Studies. Sustainability Report 2019; National Institute for Environmental Studies: Tsukuba, Japan, 2019. (In Japanese)

55. KEK Environmental Safety Office. KEK Environmental Report 2018; KEK: Tsukuba, Japan, 2018. (In Japanese)

56. Inoue, T.; Yaida, Y.A.; Uehara, Y.; Katsuhara, K.R.; Kawai, J.; Takashima, K.; Ushimaru, A.; Kenta, T. The effects of temporal continuities of grasslands on the diversity and species composition of plants. Ecol. Res. 2020, 1-8. [CrossRef]

57. Lampinen, J.; Heikkinen, R.K.; Manninen, P.; Ryttäri, T.; Kuussaari, M. Importance of local habitat conditions and past and present habitat connectivity for the species richness of grassland plants and butterflies in power line clearings. Biodivers. Conserv. 2018, 27, 217-233. [CrossRef]

58. Lindborg, R.; Eriksson, O. Historical landscape connectivity affects present plant species diversity. Ecology 2004, 85, 1840-1845. [CrossRef]

59. Cousins, S.A.O.; Eriksson, O. The influence of management history and habitat on plant species richness in a rural hemiboreal landscape, Sweden. Landsc. Ecol. 2002, 17, 517-529. [CrossRef]

60. Uchida, K.; Koyanagi, T.F.; Matsumura, T.; Koyama, A. Patterns of plant diversity loss and species turnover resulting from land abandonment and intensification in semi-natural grasslands. J. Environ. Manag. 2018, 218, 622-629. [CrossRef]

61. Noda, A.; Kondoh, A.; Nishihiro, J. Changes in land cover and grassland area over the past 120 years in a rapidly urbanised area in Japan. One Ecosyst. 2019, 4, e37669. [CrossRef]

62. Ushimaru, A.; Uchida, K.; Ikegami, M.; Suka, T. Grasslands and shrublands of Japan. In Encyclopedia of the World's Biomes; Goldstein, M.I., DellaSala, D.A., Eds.; Elsevier: Oxford, UK, 2020; pp. 785-799.

63. Ohashi, H.; Fukasawa, K.; Ariga, T.; Matsui, T.; Hijioka, Y. High-resolution national land use scenarios under a shrinking population in Japan. Trans. GIS 2019, 23, 786-804. [CrossRef]

64. Hiratsuka, M.; Hatakeyama, K.; Ohkubo, T.; Takeuchi, D. Dynamics of secondary forest and its perspective under the satoyama system in Saitama prefecture, Japan. J. For. Res. 2020, 25, 51-57. [CrossRef]

65. Jingu, S.; Take, M.; Sakata, K.; Ito, T. Study on management of a farm forest affected by change to recreational use as the Ushiku Nature Sanctuary. J. Jpn. Inst. Landsc. Arch. 2018, 81, 703-708. (In Japanese) [CrossRef]

Publisher's Note: MDPI stays neutral with regard to jurisdictional claims in published maps and institutional affiliations.

(C) 2020 by the author. Licensee MDPI, Basel, Switzerland. This article is an open access article distributed under the terms and conditions of the Creative Commons Attribution (CC BY) license (http://creativecommons.org/licenses/by/4.0/). 